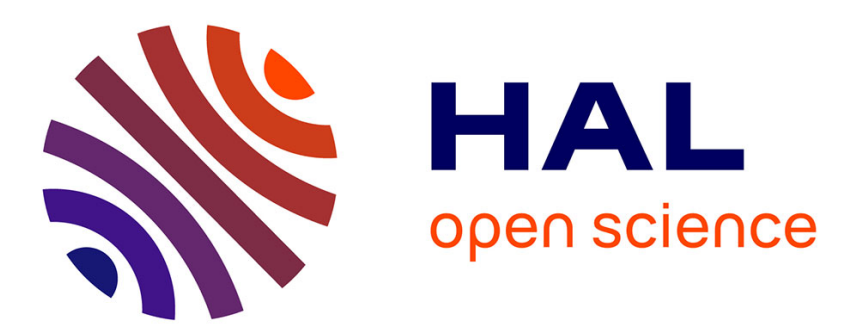

\title{
A symbolic defence of animal magnetism: a copperplate engraving by Ludwig Richter as the frontispiece of the account of the somnambulist Auguste K. (1843)
}

Luis Montiel

\section{- To cite this version:}

Luis Montiel. A symbolic defence of animal magnetism: a copperplate engraving by Ludwig Richter as the frontispiece of the account of the somnambulist Auguste K. (1843). History of Psychiatry, 2005, 16 (2), pp.203-216. 10.1177/0957154X05046075 . hal-00570814

\section{HAL Id: hal-00570814 \\ https://hal.science/hal-00570814}

Submitted on 1 Mar 2011

HAL is a multi-disciplinary open access archive for the deposit and dissemination of scientific research documents, whether they are published or not. The documents may come from teaching and research institutions in France or abroad, or from public or private research centers.
L'archive ouverte pluridisciplinaire HAL, est destinée au dépôt et à la diffusion de documents scientifiques de niveau recherche, publiés ou non, émanant des établissements d'enseignement et de recherche français ou étrangers, des laboratoires publics ou privés. 


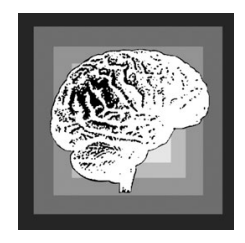

\title{
A symbolic defence of animal magnetism: a copperplate engraving by Ludwig Richter as the frontispiece of the account of the somnambulist Auguste K. (1843)
}

\author{
LUIS MONTIEL * \\ Universidad Complutense, Madrid
}

\begin{abstract}
The year 1843 saw the publication in Dresden of a comprehensive account of the magnetic treatment of a somnambulist. This date came relatively late in the history of animal magnetism in Germany, and coincided with the decline of the theory in medical circles. Perhaps it was for this reason that the authors commissioned Ludwig Richter, one of the most accomplished engravers of the day, to produce a plate of illustrations which were intended to act as a symbolic defence of the theory. They are examined in this article.
\end{abstract}

Keywords: animal magnetism; German romantic psychology; history; mesmerism; symbolic iconology

\section{Introduction: the story of an illustration}

It is probably no exaggeration to say that animal magnetism was the theory which gave the type of medicine generically labelled as Romantic its most characteristic features. ${ }^{2}$ In the climate of thought led by the desire to develop a philosophy of Nature, based both on observation and on the use of reason, the doctrine pronounced by Mesmer (and innumerable revisions, particularly by German doctors in the first decades of the nineteenth century) became a matter of passionate interest for the society of the time, and left its stamp on literature, music and the figurative arts (Barkhoff, 1995; Feurzeig, 1997; Wöbkemeier, 1990). In some cases its presence in these areas unrelated to

* Address for correspondence: Unidad de Historia de la Medicina, Facultad de Medicina, Universidad Complutense, 28040 Madrid, Spain. Email: montiel@med.ucm.es 
medicine went well beyond that of a mere motif; rather the reverse - artistic expression was at the service of medical theory.

This is true for the subject of this article. On the occasion of the publication of the details of a clinical case, that of 'Auguste K., the somnambulist of Dresden' (Bähr and Kohlschütter, 1843), a well-known artist was brought in, ostensibly to illustrate the visions of the patient, which were thought by the authors of the story to be particularly noteworthy. It is remarkable that this work, which I have been able to acquire from an antiquarian bookseller, is not mentioned in the most important bibliography on the subject, that of Adam Crabtree (1988), although it is not totally unknown to specialists. ${ }^{3}$ Until I can carry out more detailed research into the case (409 printed pages), I shall devote this article to the interpretation of the symbolic engraving which forms the frontispiece of that book (Fig. 1). It will not be a mere slavish interpretation following that proposed by the authors, which is somewhat biased in favour of their own interests.

The engraver was an artist belonging to the late Romantic school of artists, Ludwig Richter ${ }^{4}$ (1803-84), particularly esteemed in the field of woodcut illustrations and landscape painting. From 1877 he was professor of the latter in the Academy of Art in his home town of Dresden. But his activity as an engraver is undoubtedly what is most valued by present-day critics, both for sheer volume (hundreds of woodcuts, lithographs and copperplate engravings) and for quality. It is not surprising that the authors of this clinical history should choose him to reflect the visions of the somnambulist and to be more precise about the theories which the authors and their supporters based on them. The artist had returned to Dresden in 1836 (when his output of engravings had already reached 245), after study trips to France (1820-21) and Italy, notably to Rome (1823-26), and from a fruitful period working as drawing master in the Meissen porcelain factory (1828-35). ${ }^{5}$

As is customary in this type of text, the book collects in minute detail all the comments of every kind of a sixteen-year-old somnambulist, Auguste K., between 1839 and $1842 .{ }^{6}$ One of the most striking features of the case, as its authors emphasize, is that Auguste's background as a clairvoyante enables her to provide particularly valuable information about the laws of Nature and about the essence and practice of animal magnetism. While this was not uncommon in such cases, it seems that the level of information provided by this somnambulist was much better than average, and comparable only - and even favourably - with that of the already famous 'Seeress of Prevorst' of Justinus Kerner. ${ }^{7}$ This comparison, indeed, was emphasized by the authors of the story who, as we shall see, appear determined to engage in some sort of contest with their famous predecessors. The true motives for this aspiration will, perhaps, only be revealed by a line-by-line analysis of the text, but for now the interpretation of the engraving may shed some light on the subject. So may the fact, on which Gauld (1992) makes no comment, that the patient was a Protestant, a real rarity at that time and, of course, it differentiated her 


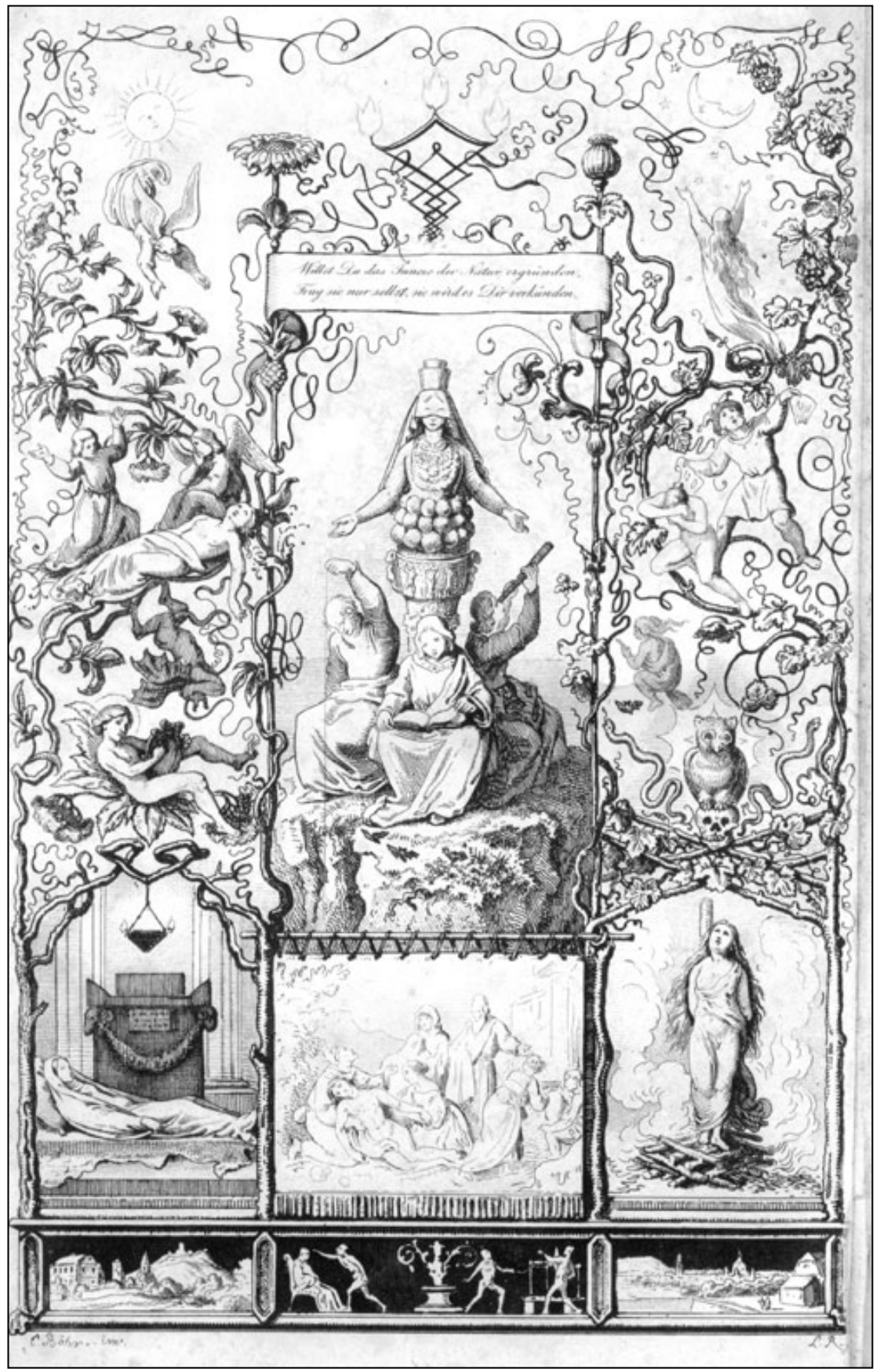

FIG. 1 Engraving by Ludwig Richter (frontispiece in Bähr and Kohlschütter, 1843) 
from the Seeress of Prevorst, Kerner himself and his circle of medical and philosophical friends. They represented that inward Catholicism, half mystic and half aesthetic, which some texts improperly attribute to German Romanticism in general. ${ }^{8}$ Be that as it may, the authors of the account claim that before taking charge of the patient they were unaware of any text on animal magnetism other than that of Justinus Kerner (Bähr and Kohlschütter, 1843: xiii); this betrays their professional status, to which they themselves soon draw attention: neither of them was a doctor (another difference, incidentally, from the Swabian Kerner who was, and no ordinary doctor at that!). ${ }^{9}$

\section{The authors of the pathographic account}

Although it is impossible to be sure, it seems, by the order in which the data are set out, that Bähr was involved in 'the plastic arts' (in what capacity, we wonder?) and Kohlschütter worked in legal administration - he was 'in the service of Themis' (and I repeat my question ...). At the time this was no bar to their involvement in the case, for it is a recognized fact that it was not generally considered necessary to be a doctor in order to be a good magnetizer. The Marquis of Puységur, one of the most important authors in the history of animal magnetism - and without doubt one of the most influential in Germany - was not a doctor (Peter, 2003). And even the rigorous Archiv für den thierischen Magnetismus, directed by Kieser, published histories of cases conducted by non-medical magnetizers. ${ }^{10}$ On the other hand, the first of the two authors is probably the Johann Karl Bahr [sic] who appears as the author of a work on animal magnetism in Crabtree's bibliography (1988: 166, ref. 652), undoubtedly the most complete on this subject.

Nor was the person to whom Bähr and Kohlschütter dedicated the book a doctor; yet, as the reading of the book reveals, he was a man dedicated to the practice of animal magnetism: Count Franz (Ferencz) Szápáry. He was a Hungarian aristocrat to whom I have found hardly any references. ${ }^{11}$ We gather (Bähr and Kohlschlütter, 1843: xxii) that he was a person of some note in Dresden, where he had a 'magnetic sanatorium' (magnetische Heilanstalt), the existence of which, as far as I am aware, is not mentioned in the specialist bibliography. He was clearly interested in medicine in general, not only magnetic, for I have found a reference to a piece he wrote about cholera, where he is described as an 'economist' or administrator, although it is not stated for what type of institution (Szápary, 1831). However, at least from 1840 onwards, his interest centred exclusively on magnetism. In that year he published the first of his works to be commented on by Crabtree (1988: 117, ref. 431 ${ }^{12}$ ): Ein Wort über animalischen Magnetismus, Seelenkorper [sic] und Lebensessenz; nebst Beschreibung des ideo-somnambulen [sic] Zustanden des Fräulein Therese von B-y zu Vasarhely im Fahre 1838, und einem Anhang (Leipzig: F. A. Brockhaus). Notice that in this reference there already 
appears an error which was to be obstinately perpetuated in later works: the alteration of his German title Graf to Grof, an error which seems to have arisen during his period in France, to which I shall refer below. In 1845 he published another two works on the subject (Crabtree, 1988: 138-9, refs $527,528)$, in which the present case has a decisive influence. In the first, whose title declares its purpose of serving 'lay' magnetizers (i.e., not doctors), he admits - according to Crabtree's index - that he really only began to understand magnetism from 1843 on, and precisely as a consequence of the declarations of "his' ${ }^{13}$ somnambulist Auguste Kachler (whose surname was now made public for the first time). Not least among these was that it is not necessary to be a doctor to be a magnetizer. From this time, Count Szápáry's interest shifts - following, indeed, the evolution of animal magnetism itself at this late stage - towards the occult. His activities moved to neighbouring France, where he founded a 'Pariser-deutschmagnetische Schule', in the midst of which the romantic figure of the somnambulist changed into the more spiritual figure of the medium, and which produced works particularly concerned with the fashionable phenomenon of tables which move on their own (Crabtree, 1988: 183, refs $\left.730,731^{14}\right)$.

Having described the authors Bähr and Kohlschütter, I will now introduce the person who inspired them. In one sense, as the authors would gladly agree, Auguste $\mathrm{K}$. was the true author, since they did no more than transcribe, attentively and reverently, the declarations of the somnambulist, endowed with clairvoyance which enables her to observe what they, common folk, cannot divine. Auguste K. was a young woman from a not particularly wealthy bourgeois family in Dresden; when she was sixteen, she bathed in the Elbe shortly after the onset of menstruation, which then stopped, accompanied by cramps and convulsions. This condition led to her magnetic state (Bähr and Kohlschütter, 1843: 3), which was to last for two years (July-August 1839 until August 1841). While in that state she came to exemplify the doctrine which Count Szápáry was to adopt as his own, and the translation of which into symbols I shall now describe.

\section{The authors' interpretation}

In the text devoted to 'the title engraving' (Erklärung des Titelkupfers), Bähr and Kohlschütter (1843: xxi-xxii) say that it displays 'the primordial forces of Nature, according to the way they are absorbed by the patient and the effect they have upon her', faced with 'fiercely adverse attitudes [to belief in these forces] since most ancient times: superstition and scepticism' ${ }^{15}$ This ambiguous statement might lead to the belief, especially among those who had had access to the numerous stories of the genre already published and distributed to the public, that the images were derived directly from Auguste's somnambulistic states. Far from it: if anything, the composition seems to 
have been independently designed by Richter, for at least one of its symbols the tapestry with the scene of the Good Samaritan - can be explained by alluding to what the artist himself wished to express. But in addition, a first reading of the work has enabled me to realize that only a few of the themes are closely related to the declarations made by the somnambulist in her state of trance, generally in reply to very specific questions put by Bähr and Kohlschütter. This impression is confirmed by a reading of their interpretation of some of the figures, which could hardly have been produced by a young woman with basic schooling and with no noticeable reading ${ }^{16}$ such as, for example, the figure in the bottom left-hand corner representing a sleeping woman who, according to the explanation in the text, is undergoing the classical ritual of incubatio.

As far as the interpretation of the engraving is concerned, I shall closely follow the guidelines of the text's authors, adding any comments I feel necessary. To begin with, the writers explain that the plate should be divided vertically into three parts. The left-hand column shows 'the diurnal part, the sun, with its magnetic influence, the high degree of concentration of magnetic force, the stimulation of spiritual activity and relaxation of the body'; that on the right is 'the nocturnal part, the moon, with its stimulating electrical force, a high level of sensual arousal, the withdrawal of the spirit'. Note that the two columns are separated from the centre by the long stalk of the same symbolic plant, the sunflower, whose flower closes under the moon's rays and opens under those of the sun.

At this point, a couple of terminological points should be clarified. The first concerns 'spirit'; this is the most literal translation of the German Geist, although in the context of the newly developing psychology it could sometimes be translated as 'psyche', for only later would a clear distinction be drawn between the two disciplines. Thus, in the the description for the left column just quoted, it would be possible to write 'psychic activity' instead of 'spiritual activity'. The second point refers to terms which I have chosen not to translate in the preceding text, but which are of great importance within the clinical history. At the end of the description relating to the left-hand side of the illustration, the authors put the term Gehirnsomnambulismus in brackets, and then refer to the right-hand side as Mondsucht. This gives us a slight problem, since it is quite clear that the former should be translated as 'cerebral somnambulism'. But the translation of Mondsucht into English is also 'somnambulism' or 'sleepwalking', since this classic German word (which may be literally translated as 'being moonstruck' or 'obsession with the moon') describes the phenomenon, observed since antiquity, that certain people may walk about in their sleep, and by extension perform other activities of normal life such as speaking. For German authors of the time, 'somnambulism' was a neologism proceeding directly from the work of Mesmer, and was of course a technical term denoting a new phenomenon, only apparently similar, or only in some facets, to the peculiar condition known as Mondsucht. 
Having clarified this, from now on I shall use the German words to avoid confusion.

Throughout the account Auguste refers to herself as a Gehirnsomnambule, and stresses that the condition is caused by magnetism, while Mondsucht is the work of electricity; indeed she ascribes the magnetic influence on living beings to the sun and electrical influence to the moon. This is her principal contribution to the engraving, since practically everything the authors say from now on to explain the pictures is their own invention.

The first figures they deal with are the two at the foot of the left and right columns. The one on the left - in the solar column - represents 'sleeping in the temple', or incubatio, the religion-based therapeutic technique which was practised in ancient Greece in the temples dedicated to Asclepius, the god of medicine. This technique, as we know, aimed to cure patients or else to provide them, while asleep, with some piece of dietary or therapeutic advice from the god himself, which, if followed, would help them to recover their health. This ancient technique had already attracted the attention of the great theorists of magnetism, due to its similarity to what was expected of the state of somnambulism (Carus, 1930/1964: 99n.; Kieser, 1826: II, 38-41; see also Montiel, 1997) ${ }^{17}$ In their brief comment on the figure the authors say that this technique explains 'the veneration of the ancients for the decisions of Nature'. On the other hand, the figure on the right represents 'a witch at the stake'. As explained in the footnote, 'witches were for the most part somnambulists'. ${ }^{18}$ This gloomy image is intended to represent 'the scepticism ${ }^{19}$ of the Middle Ages and the hostility towards the still incomprehensible manifestations of Nature'.

\section{The 'solar' and 'lunar' columns}

Let us, as they do, continue to move up the lunar column: 'above the woman condemned to die by fire', they say, 'there is an owl perched on a skull, symbolizing the sinister scholar who seeks to study human nature through inanimate remains'. About his head there shines 'an electric spark'. The serpents represent 'the poison of slander, which he heaps upon everything he cannot understand'. He is, they tell us, incubating, which can be interpreted as the idea that 'anything in which he does not believe cannot exist'. However, behind him flies a witch. The footnote just quoted states that witches were unaware of their condition as somnambulists and thought they could fly and hover in the air. In other words, somnambulism exists, no matter what the 'scholars' say, but it is still unknown and given over to the powers of darkness. Note, too, that the flying witch is accompanied by a bat. By the way, this insistence on matters electrical seems to reveal the conviction that electricity, which is beginning to be understood and even controlled by laboratory physicists, scientists, now forms part of that branch of knowledge which 'denaturalizes', and feeds off dead matter. 
Going up another level we find a man wearing a cap of bells - the distinctive garment of the jester (in German Hofnarr, court fool) - 'who has captured Psyche and, to prevent her flying away, tears off her delicate wings'. The authors make use of the association, familiar since classical antiquity, between the idea of Psyche as soul and the figure of the butterfly (the living, flying result of the metamorphosis of an inferior being, the caterpillar, during a period of absolute stillness resembling death). But again, as in the case of the 'sinister scholar'/owl, natural facts whose existence others seek to deny persist in manifesting themselves: 'above this group can be seen a figure drawn by the force of the moon, a sleepwalker (Mondwändlerin)'.

The figures in this column are at the same time interwoven and separated by the tendrils of a readily recognizable plant, although the authors, in case of any doubt, identify it as a vine. As we know, the vine is, together with ivy, the symbolic plant of Dionysus; and there was no need to wait for Nietzsche for it to be quite clear that Dionysus represents the nocturnal and pulsive side of human existence: Creuzer, in his Dyonisos (1805-06) had already acquainted his contemporaries with this deity. On the other hand, the plant which performs the same function in the solar column is an elder - and in this case, at least for me, the authors' description is absolutely necessary. Although, as in the previous case, they give no reason for their choice, I take it to be due to the symbolic value which is attached to this bushy plant among Germanic peoples. According to a belief passed on by Gustav Meyrink (1981: 131), it is thought to be endowed with extraordinary powers, because if it is uprooted and replanted upside down the branches become roots and vice versa. In other words, it is a symbol of renewal and, even more, of rebirth into another form of existence. In E. T. A. Hoffmann's tale Der goldene Topf (The Golden Pot), the spiritual adventure of the hero, which will lead to his transfiguration from a clumsy student into an enlightened poet, begins in the shade of an elder tree (Montiel, 1995). Bähr and Kohlschütter tell us that from the place where the roots of the elder tangle with those of the vine - 'magnetic agitation (Erregung) with electrical' -there sprouts 'the eternal flame of life, galvanism'. This mention of galvanism, especially presented as something distinct from electricity, is an anachronism ${ }^{20}$ which confirms the scant scientific training of the authors of the text.

Let us now move on to the solar column, that of magnetism, where 'imagination takes untrammelled flight'. This is represented especially by the youth who, above the scene of sleeping in the temple, 'with his hair encircled by the colours of the rainbow, looks ecstatically into a magic mirror'. 'Everything which takes his fancy', continue the authors, 'appears to him in this mirror with the colours and movement of real life'. Further up a woman can be seen sleeping in a magnetic trance, watched by her 'faithful ${ }^{21}$ observers', no doubt a representation of the situation described in the account. She contemplates her protecting angels, as well as a demon expelled by them. 


\section{The veiled truth}

From here the authors move on to describe the central part of the plate. Its principal figure is 'the symbol of Nature, Isis' - clearly not the Egyptian Isis, but that other one, veiled, whom the 'Novices of Sais' in Novalis' homonymous work sought to meet. The men surrounding her are trying, cautiously and reverently, to decipher her mysteries: 'One of them looks through the dark night towards the limitless distance of the celestial world; another plumbs the unexplored depths; the third holds before him a book to compare and interpret'. The birds fluttering round their feet represent the permanent threat of defamation.

What follows is particularly interesting, since it makes us aware of the existence of something which, like Isis' face, is not to be seen: 'behind the curtain - the cloak of love - the artist has imagined the present day, where the followers of superstition and those of disbelief are embroiled in a violent struggle'. The scene which can be seen on the cloak is that of the Good Samaritan. Our attention is drawn to the clever psychological trick of using what cannot be seen for educative or propaganda purposes, although this provocative technique does make it necessary to have a commentary - in other words, the direct intervention of the propagandist on his listener. On the one hand this suggests the idea of great tactfulness, saving the viewer the sight of the conflicts; on the other hand, the desire to make them disappear under the cloak of disinterested love, which only seeks the good of whoever needs it most. But it is also true that this approach introduces a certain imbalance into the picture since, if we are to understand that the authors are on the 'solar' side (but we shall see later that this not wholly the case), the controversy covered by the Samaritan's curtain leaves the 'superstitious' in a rather embarrassing position. We have already seen that the medieval 'witch' is being burnt by the 'sceptics', among whom are those who practice incubatio (representatives, they tell us, of 'grey antiquity'), and probably, too, the fantasist gazing into his magic mirror.

So we come to the base of the picture, perhaps the part which is most heavily laden with propagandist intentions. To the right we are shown 'the city of Dresden from the country house accommodating Count Szápáry's magnetic sanatorium': that is, to the scene of the action. Surprisingly, at least in view of what has been said, it is on the 'side of the sceptics, where electricity rules'. On the other side, that of 'superstition and magnetism', is the image of Weinsberg which 'shows in the foreground a house which has a certain renown in the history of magnetism'. This is, of course, the famous Kernerhaus, the house where Justinus Kerner lived and frequently treated his somnambulists, including the Seeress of Prevorst. It is recognizable not only from its appearance but also by the ruins of Weibertreu castle in the background of the picture. Between the two magnetic sanctuaries is a 
representation of the two therapeutic techniques: next to the Kernerhaus 'a patient is magnetized and falls asleep'; next to the view of Dresden 'another, electrified with the aid of a machine, struts along'. The cryptic comment on this striking reversal of roles is as follows: 'let the thoughtful reader consider what the author has tried to imply by these pictures, and by the place which he has assigned to each of them'.

As a 'thoughtful reader', I suspect that this enigmatic statement hides a criticism of the undoubtedly unfavourable welcome which the theories and practices of Count Szápáry and his followers received from the scientific institutions of the capital of Saxony. Indeed, anyone who read through to the end of the explanation of the engraving proposed by the authors might well expect to find the symbol of their proposal at the base of the solar column, although as we have seen some ambiguous judgements have slipped into the explanation of some of the figures constituting it. How are we to take what they say about 'fantasy' and 'credulity'? And above all there is the epithet of 'superstitious' which is applied to a good deal of what is shown. Even so, it is a question of the 'magnetic' column as opposed to the 'electrical' column on the right. We might even expect that, in a show of self-confidence, they might place themselves in the middle, at the feet of Isis and under the cloak of the Good Samaritan. And to a certain extent that is the case, although again in a negative way: rather, they are covered by the cloak of invisibility, that invisibility to which I believe they were condemned by the official scientific bodies of Dresden. Justinus Kerner is their rival; he is Catholic and superstitious. Did he not go so far as to confirm that magnetism proves the existence of an underworld inhabited by spirits who, from time to time, can break through into ours? 22 $^{22}$ Yet he believes in animal magnetism, he practises it and in the course of doing so he has bestowed on this much-criticized practice a distinction which the authors recognize in their text. That is why the scene shown in this picture is precisely the Kernerhaus. On the other hand, Count Szápáry's Magnetic Sanatorium, which we should so much like to see, appears nowhere. We only see the triumphant city of Dresden devoted, it seems, to laboratory science: that science which, according to the authors, seeks to investigate life through death, and with whose approval the patient is electrified using machines. ${ }^{23}$ Instead of the peaceful sleep offered by magnetism, it produces the dreadful effect of a jerking, mechanical gait like that of the unsettling automata which inhabit the tales of E. T. A. Hoffmann.

\section{Conclusion}

In my opinion the illustration examined performs a strictly propagandistic, even defensive role at a moment when animal magnetism is beating a retreat on all fronts. The old controversy about the need for the magnetizer to be a doctor is now practically meaningless, as is shown in the story of this case whose authors (including Count Szápáry in the background) are not medical 
men. This is surely because very few doctors would now be interested in taking credit for this procedure for treating patients, where the psychic component is predominant. They are not content to put forward as their argument the longwinded description of a protracted treatment, perhaps doubting that many would read it, but also aware that the somnambulist's testimonies only indirectly serve their interests. So they use an expedient: symbolism, which, deeply rooted in the Renaissance tradition that confers a certain prestige, operates in this case together with the newly discovered rhetoric of graphic propaganda. Thus they bequeath to us a work of art, a minor work if you like, but not devoid of quality, which allows us to examine with a fresh eye a part of this fascinating period of the history of the medicine of the mind.

\section{Notes}

1. Proyecto BHA 2000-0721.

2. Unequivocal proof of this is the title of one of the books dedicated to the subject (Treichler, 1988); translation of the title: The Magnetic Age: Daily Life and Life Sentiment in the Early 19th Century. From among the authors considered as classics in the study of Romanticism, I have selected the following testimonies: Huch (1978-79: II, 226): 'Now linked to Romanticism by the Philosophy of Nature, medicine finally became a romantic science when it took control of Mesmerism or animal magnetism'; Beguin (1981: 91): 'Magnetic therapy enjoyed unheard-of popularity, and the philosophers of salons and universities had a splendid arena for arguments, ludicrous theories and elaborate explanations'; Gusdorf (1993: II, 534): 'Animal magnetism, a quintessential contribution to Romantic intelligibility ...' The most conclusive declaration on the subject comes from the man who really originated research into the medical science of German Romanticism, Werner Leibbrand (1956: 174): 'Without animal magnetism, medical Romanticism would never have become anything more than a mere torso'.

3. So far I have found only a single reference, a few lines long, in Allan Gauld's admirable History of Hypnotism (1992: 152-3).

4. The plate is signed on the right with his initials, L.R., and his authorship was confirmed by the biographer and student of Richter's work, J. F. Hoff (1922).

5. Information taken from: Ludwig Richter, Maler und Zeichner, 1803-1884. Retrieved from: http://www.saxonia.com/galerie/richter.htm

6. Years later the patient's surname, Kachler, was to be revealed (see below in text). I should like to mention that Gauld (1992) condemns, in my view unfairly, the long-windedness of the authors which makes the text 'tedious', as well as the 'reverence and credulity' towards the somnambulist. The former criticism is particularly unfortunate, in my view, since in my experience this thirst for detail - even the most trivial - is far from uncommon in this type of text, and may also be explained by the novelty of the material and its mysterious background, which urges the authors to ignore nothing that might have any significance. See Montiel, 1990, 2001, 2003.

7. Friederike Hauffe, the Seeress of Prevorst, is without a doubt the best-known case of visionary somnambulism in German Romanticism. Her doctor, Justinus Kerner, published an extensive report - Die Seherin von Prevorst (1829) - about the case which, starting from the observation of the patient, leads to a whole philosopho-mystic theory about the existence of a spirit world that can manifest itself in our own. The work, widely 
read in its day, later became a reference for spiritualists and occultists. Details of this subject may be found in the study by Grüsser (1987) and in Montiel (2002).

8. The tension between Protestantism and Catholicism within animal magnetism is something I have noted previously (Montiel, 2001: 74); Kieser, for example, credits Lutheran thought with a more critical and cautious attitude than the Catholic view, more prone to be carried away by fantasies within the shady world of magnetism.

9. Kerner was municipal doctor in different parts of the Swabian countryside, finishing up in Weinsberg, where his house is now a museum. But he also ventured into medical research and achieved an understanding of botulinus poisoning which was extremely accurate for his time (Grüsser, 1987: 130).

10. For example, that of the 'clairvoyante Maria Rübel, of Langenberg', reported by A. Köttgen (who, to judge by the way he refers to himself, was not a doctor) and published by Kieser himself. This is another text which has excited my curiosity, and which is awaiting study.

11. In Gauld's History of Hypnotism (1992), as well as in the no less monumental work of Méheust (1999), I have been able to find the name of this character mentioned only once: in the case of Gauld, as noted earlier, and with a simple reference to his work on 'moving tables' (see below in text); the other reference is in Méheust (1999: I, 315). The richest source of information is Crabtree's (1988) bibliography.

12. The author's name appears in its Hungarian version, Ferencz, followed by the incorrect 'Grof'.

13. This appropriation seems only partially unwarranted. As we have seen, Bähr and Kohlschütter (1843) dedicate the work to him, thus granting him a certain importance. Moreover, although his presence is only noted in passing at certain moments in the account, the authors explain at the end that the Count could only join the case belatedly due to his absence from Dresden (p. 407).

14. It is noteworthy that in the second reference the title is half in English and half in German. Food for thought!

15. All translations are mine.

16. Among the documents included by the authors of the story as a preamble is a report from the evangelical school where Auguste did her elementary education (pp. xvii-xix) which, as well as emphasizing the girl's great imagination, specifies that the knowledge acquired there is no more than what is necessary for her to perform as a pious housewife, capable of reading and writing with ease.

17. In 1844, or one year after the publication of the subject work, there appeared in Leipzig (Brockhaus) the first part, Geschichte der Magie, of the projected Geschichte der thierischen Magnetismus by Joseph Ennemoser. Pages 506-515 are devoted to explaining sleep in the temples of Asclepius from the point of view of animal magnetism.

18. This theory is also expounded in Kieser's (1826) work, which retrospectively investigated a supposed case of demonic possession from the point of view of animal magnetism. See Montiel, 2001: 72-9.

19. Another term difficult to translate, for Unglaube can equally well mean 'scepticism', 'unbelief' or 'faithlessness', all concepts which can hardly be applied to our image of the Middle Ages. No doubt the authors propose this Unglaube from their own naturalist viewpoint, and not in the more traditional religious sense.

20. Already in 1800 Volta had shown experimentally the non-existence of the 'animal electricity' wrongly discovered by Galvani, although during the early years of the century the news does not seem to have reached the ears of many Naturphilosophen. However, in 1820 a physicist disciple of Schelling (familiar, that is, with his Naturphilosophie), Hans Christian Oersted, discovered electromagnetism in his eagerness to discover a force 
unique in Nature, following the dictates of that philosophy. Years later, but in any case before the publication of the text we are studying (in 1822 and 1831), the Englishman Faraday had perfected the scientific study of electromagnetic phenomena. At all events, since the publication of Oersted's research it had been known that the association of electric and magnetic currents produced no 'galvanism', although it is true that Bähr and Kohlschütter were referring to 'animal magnetism' rather than mineral, which was what physicists studied.

21. The term used here appears to have a religious sense, that of 'believer': 'gläubigen Beobachter' is the textual reading.

22. See Note 7.

23. The machine shown in the picture appears to be one used to produce static electricity by friction.

\section{References}

Bähr, J. K. and Kohlschlütter, R. (eds) (1843) Mittheilungen aus dem magnetischen Schlafleben der Somnambule Auguste K. in Dresden (Dresden/Leipzig: Arnold).

Barkhoff, J. (1995) Magnetische Fiktionen. Literarisierung des Mesmerismus in der Romantik (Stuttgart: Metzler).

Beguin, A. (1981) El alma romántica y el sueño (México: Fondo de Cultura Económica).

Carus, C. G. (1964) Psyche. Zur Entwicklungsgeschichte der Seele (Darmstadt: Wissenschaftliche Buchgesellschaft); facsimile of the Pforzheim edition, 1830.

Crabtree, A. (1988) Animal Magnetism, Early Hypnotism and Psychical Research (White Plains, NY: Kraus).

Feurzeig, L. (1997) Heroines in perversity. Marie Schmith, animal magnetism, and the Schubert circle. 19th Century Music, 21(2), 223-43.

Gauld, A. (1992). A History of Hypnotism (Cambridge: Cambridge University Press).

Grüsser, O. J. (1987) Fustinus Kerner 1786-1862. Arzt - Poet - Geisterseher (Berlin: Springer).

Gusdorf, G. (1993) Le Romantisme (Paris: Payot).

Hoff, J. F. (1922) Adrian Ludwig Richter, Maler und Radierer. Verzeichnis seines gesammten graphischen Werkes (Freiburg i.Br.: Ragocy).

Huch, R. (1978-79) Les romantiques allemands (Aix-en-Provence: Pandora).

Kieser, D. G. (1826) System des Tellurismus oder Thierischen Magnetismus (Leipzig: Herbig).

Leibbrand, W. (1956) Die spekulative Medizin der Romantik (Hamburg: Claasen).

Méheust, B. (1999) Somnambulisme et médiumnité (Le Plessis-Robinson: Synthelabo).

Meyrink, G. (1981) Der weisse Dominikaner (München: Langen Müller).

Montiel, L. (1990) Una historia clínica romántica. Contribución al conocimiento de la patología de la naturphilosophie. Medicina e Historia, 31, 1-16.

Montiel, L. (1995) Un cuento de hadas sobre la vida del inconsciente. El caldero de oro, de E.T.A. Hoffmann. Fano, 48, 39-44.

Montiel, L. (1997) Materia y espíritu: el inconsciente en la psicología de Carl Gustav Carus (1779-1868). Dynamis, 17, 213-37.

Montiel, L. (2001) Historia y enfermedad mental en dos historias clínicas de Dietrich Georg Kieser (1776-1862). Frenia, 1(2), 67-85.

Montiel, L. (2002) Kleksografias de Justinus Kerner. Selección, traducción y estudio preliminar. Frenia, 2(2), 121-46.

Montiel, L. (2003) La novela del Doctor Klein. Relato de una terapia magnética en el Romanticismo alemán. In L. Montiel and A. González de Pablo (eds), En ningún lugar. En parte alguna. Estudios sobre la historia del magnetismo animal y del hipnotismo (Madrid: Frenia), 101-41. 
Peter, J. P. (2003) Lo que los magnetizadores nos han enseñado (De Mesmer a Puysegur). In L. Montiel and A. González de Pablo (eds), En ningún lugar. En parte alguna. Estudios sobre la historia del magnetismo animal y del hipnotismo (Madrid: Frenia), 35-61.

Szápáry, Graf Franz von (1831) Flugschrift eines Oekonomen über einige höchst bedeutende Ursachen der seit mehreren fahren unter unsern Augen so sichtbar zunehmenden Krankheiten, vorzüglich der Fieber und der so gefürchteten Cholera (Pest: Otto Wigand).

Treichler, H. P. (1988) Die magnetische Zeit: Alltag und Lebensgefühl im frühen 19. Fahrhundert (Zurich: SV International/ Schweizer Verlagshaus).

Wöbkemeier, R. (1990) Erzählte Krankheit. Medizinische und literarische Phantasien um 1800 (Stuttgart: Metzler). 